\title{
Borrelia turcica in Hyalomma aegyptium ticks in Romania
}

\author{
Z Kalmár ', G D’Amico, IA Matei, Al Paștiu, DI Mărcuțan, MO Dumitrache, AD Mihalca \\ From The 1st Conference on Neglected Vectors and Vector-Borne Diseases (EurNegVec): with Management \\ Committee and Working Group Meetings of the COST Action TD1303 \\ Cluj-Napoca, Romania. 8-11 April 2014
}

Testudo graeca tortoises are distributed in the southeastern part (Dobrogea region) of Romania. T. graeca is a potential host for the three-host ticks, Hyalomma aegyptium. $H$. aegyptium ticks are important from epidemiological point of view as they constitute potential reservoirs for numerous zoonotic bacterial pathogens (Anaplasma phagocytophilum, Ehrlichia canis, Coxiella burnetii). However, $H$. aegyptium was reported to host less studied bacteria, non-Lyme members of genus Borrelia. Despite its relatively wide distribution range, the extent of co-distribution of ticks with these bacteria was not investigated in detail. The aim of the present study was to evaluate $H$. aegyptium engorged ticks collected from tortoises in south-eastern Romania for the presence of non-Lyme Borrelia. Between 2008 and 2013, 448 H. aegyptium ticks were collected from $45 \mathrm{~T}$ graeca tortoises located in Dobrogea region in Romania. DNA extraction was performed individually from each tick using a commercial kit. For the total 78 (17.4\%) Borrelia spp. positive ticks, PCR analysis targeting the intergenic spacer $5 \mathrm{~S}-23 \mathrm{~S}$ region, $g l p Q$, respectively $g y r B$ genes, and further sequencing was performed for the further identification. Sequences of $\operatorname{gyr} B$ and $g l p Q$ genes showed $99 \%-100 \%$ similarities with reptile-associated Borrelia turcica. The most frequently infected stages were males $(10.7 \%$ of the total males examined or $61.5 \%$ from the total infected ticks) followed by females $(5.36 \%$ of the total females examined or $31 \%$ from the total infected ticks) and nymphs (1.34\% of the total nymphs examined or $7.7 \%$ from the total infected ticks). This is the first report of Borrelia turcica in Romania.

This research was supported by grant CNCSIS IDEI PCCE 7/2010 and IDEI PCE 236/2011.

\footnotetext{
* Correspondence: zsuzsa_kalmar@yahoo.com

Department of Parasitology and Parasitic Diseases, University of Agricultural Sciences and Veterinary Medicine Cluj-Napoca, Cluj-Napoca, Romania
}

Published: 1 April 2014

doi:10.1186/1756-3305-7-S1-P6

Cite this article as: Kalmár et al:: Borrelia turcica in Hyalomma aegyptium ticks in Romania. Parasites \& Vectors 2014 7(Suppl 1):P6.

\author{
Submit your next manuscript to BioMed Central \\ and take full advantage of: \\ - Convenient online submission \\ - Thorough peer review \\ - No space constraints or color figure charges \\ - Immediate publication on acceptance \\ - Inclusion in PubMed, CAS, Scopus and Google Scholar \\ - Research which is freely available for redistribution \\ Submit your manuscript at \\ www.biomedcentral.com/submit
}

C Biomed Central

C 2014 Kalmár et al.; licensee BioMed Central Ltd. This is an Open Access article distributed under the terms of the Creative Commons Attribution License (http://creativecommons.org/licenses/by/4.0), which permits unrestricted use, distribution, and reproduction in any medium, provided the original work is properly cited. The Creative Commons Public Domain Dedication waiver (http:// creativecommons.org/publicdomain/zero/1.0/) applies to the data made available in this article, unless otherwise stated. 